\title{
An Innovative Study on Reuse of Demolished Concrete Waste
}

Yadhu G* and S Aiswarya Devi

K.S.R.College of Engineering, Thiruvalla, Kerala, India

\begin{abstract}
Nowadays the greatest crisis faced by the construction industry is the availability of sand. As the digging of river sand destroys the river bed and causes danger for people using the river, digging of river sand has been made illegal in most rivers. So getting river sand is really expensive nowadays as its availability is very limited. So more importance is now given nowadays for replacement of river sand as fine aggregate. Mostly used nowadays in Kerala is M-Sand. In our project we are trying to replace sand with crushed used (demolished) concrete. The concrete created with this aggregate showed almost the same strength of concrete with natural sand. This is not only much cheaper than river sand and $\mathrm{M}$ sand, but also helps to decrease the disposal of construction wastes, which environmentalists say degrades the land. So in the end use of this crushed concrete is beneficial not only to the contractor but also to our environment. This is an experimental study to see the feasibility of C\&D wastes as fine aggregate in concrete.
\end{abstract}

Keywords: Concrete waste; Concrete waste reuse, Construction waste, Lean construction; M sand; Sand; Save environment

\section{Introduction}

Concrete is everywhere. Wherever humans have inhabited, concrete is there. Homes, schools, hospitals, offices, roads and footpaths all make use of concrete. Concrete is an excellent material to make long-lasting and energy-efficient buildings. However, even with good design, human needs change and potential waste will be generated. Changes in infrastructure planning and needs result in the generation of construction and demolition waste (C\&D Wastes): an estimated 900 million tonnes every year in India, Europe, the US and Japan. Building and constructions is a cyclic process and the recycling of these wastes has several advantages. C\&D wastes are based upon the building materials. As in worldwide first these wastes are used for land filling. Concrete reuse is primarily related to a project's location.

Demolition of old and deteriorated buildings and traffic infrastructure, and their substitution with new ones, is a frequent phenomenon today in a large part of the world. The main reasons for this situation are changes of purpose, structural deterioration, rearrangement of a city, expansion of traffic directions and increasing traffic load, natural disasters (earthquake, fire and flood), etc. For example, about 850 million tons of construction and demolition waste are generated in the EU per year, which represent $31 \%$ of the total waste generation [1]. In the USA, the construction waste produced from building demolition alone is estimated to be 123 million tons per year [2]. The most common method of managing this material has been through its disposal in landfills. In this way, huge deposits of construction waste are created, consequently becoming a special problem of human environment pollution. For this reason, in developed countries, laws have been brought into practice to restrict this waste: in the form of prohibitions or special taxes existing for creating waste areas. On the other hand, production and utilization of concrete is rapidly increasing, which results in increased consumption of natural aggregate as the largest concrete component. For example, two billion tons of aggregate are produced each year in the United States. Production is expected to increase to more than 2.5 billion tons per year by the year 2020 [2]. This situation leads to a question about the preservation of natural aggregates sources; many European countries have placed taxes on the use of virgin aggregates. Sustainable construction rather than a fancy idea now is a necessity. Concrete industry, which uses 12.6 billion tons of raw materials each year, is the largest user of natural resources in the world [1]. On the other side when a building is demolished after its use, for repairs or for deterioration it generates large amount of $C \& D$, which conventionally and till today is used for land filling. In recent years, the recyclable potential of construction and demolition $(C \& D)$ waste has made it a target of interest and the main focus of waste management policies on encouraging minimization, reuse, recycling, and valorization of the waste as opposed to its final disposal in landfills. For example, limited availability of materials in a particular region may result in a cost-effective use of equipment and manpower to remove nearby concrete structures with the intent of reusing the removed materials as a roadway base or as coarse aggregate for concrete. Most concrete mix designs can be improved to reduce $\mathrm{CO}_{2}$ footprints by Use of recycled concrete as aggregates, where appropriate. The use of recycled concrete as granular base has been increasing rapidly. For example, at Toronto's Pearson airport, 145,000 t of concrete from old terminals and pavements was crushed on site and recycled for use in $500 \mathrm{~mm}$ thick granular base layers under new apron and taxiway pavements. Over $75,000 \mathrm{t}$ of RCA were used for this purpose thus saving approximately 4000 truckloads of virgin granular base from being hauled more than $50 \mathrm{~km}$ from quarries to the airport and a similar number of truckloads of old concrete being hauled away to landfill. The ultimate purpose of recycling [3] materials is to minimize the impact of human activities on the environment and the planet. From this viewpoint, the first priority of concrete engineers is to maximize the lifespan of concrete structures, at least concerning category 2, because buildings and infrastructures must be used for a very long time and, reuse of concrete and/or recycling of concrete materials is not easy technically or economically. Also the waste from concrete structures should be reduced before considering how to reuse or recycle it. It is estimated that 1 billion tons of construction and demolition (C\&D) waste are generated annually worldwide. Whether $C \& D$ waste originates from clearing operations after natural disasters (e.g., major earthquakes) or from human-controlled activities, the utilization of such waste by recycling can provide economic and environmental benefits. In recent years, utilizing $C \& D$ waste for new construction through recycling and reuse has received increased attention throughout the world.

*Corresponding author: Yadhu G, K.S.R.College of Engineering, Thiruvalla Kerala, India, Tel: 9094675824; E-mail: yadhupanicker@gmail.com

Received June 17, 2015; Accepted August 17, 2015; Published August 27, 2015

Citation: Yadhu G, Aiswarya Devi S (2015) An Innovative Study on Reuse of Demolished Concrete Waste. J Civil Environ Eng 5: 185. doi:10.4172/2165784X.1000185

Copyright: (C) 2015 Yadhu G, et al. This is an open-access article distributed under the terms of the Creative Commons Attribution License, which permits unrestricted use, distribution, and reproduction in any medium, provided the original author and source are credited. 


\section{Materials Used}

\section{Material specification for concrete preparation has been discussed below}

Cement: Cement is produced by burning together, in a definite proportion, a mixture of siliceous (containing silica), argillaceous (containing alumina) and calcareous (containing lime) material in a partial fusion, at a temperature of 1400 to $1450^{\circ} \mathrm{C}$. By doing so, a material called clinker is obtained. It is cooled and then grounded to the required fineness to get cement. Different types of cement are obtained by varying the proportions of the raw materials and also adding small percentage of other chemicals.

Three types of cement are available in Indian Market. They are:

1. Ordinary Portland Cement (OPC) may be used in normal conditions

2. Portland Pozzolona Cement (PPC) may be used in normal condition but after checking the mortar setting

3. High-early-strength Cement (quick setting cement) may be used in cold climate zones and also in places where early setting and strength gaining is desirable.

In the project we have used Ordinary Portland Cement.

Aggregate: A mixture of only cement and water is costly and possesses low strength and shrinks unacceptably on drying shrinkage. In order to reduce the cost and modify such properties as the strength and drying shrinkage of the hardened mass, it is usual to introduce insoluble non cementitious particles described as aggregates. Such aggregates usually constitute between 50 to $80 \%$ of the volume of conventional concrete and may thus greatly influence its properties. Aggregate should not contain any constituent which affects the hardening of the cement and durability of the hardened concrete adversely. It should be free from organic matter which reduces the hydraulic activity of cement and affects its normal setting and hardening. It should also be free from occupies which decompose or change significantly in volume on exposure to atmosphere, or react adversely with the hardened cement paste.

Classification of aggregate: Aggregates are classified based upon their size as

a) Coarse aggregate and

b) Fine aggregate

a) Coarse aggregate: Coarse aggregate is material which passes through $80 \mathrm{~mm}$ sieve and retained on a $4.75 \mathrm{~mm}$ sieve. It may be uncrushed gravel if it results from the natural disintegration of rock or crushed stone or crushed gravel if it is produced by crushing hard stone, gravel.

In the project we have used crushed stone as coarse aggregate.

b) Fine aggregate: Fine aggregate is material which passes through $4.75 \mathrm{~mm}$ sieve and retained on 75 micron sieve. It may be natural sand if it results from the natural disintegration of rock or crushed stone sand or crushed gravel sand if it is produced by crushing hard stone or gravel, respectively.

In the project we have used river sand and crushed $C \& D$ wastes $[4,5]$ as fine aggregate.

Water: Water used for making and curing concrete should be free from injurious substances such as oil, acid, alkali, sugar, salt, organic materials or other elements deleterious to concrete or steel. Portable water is suitable for making concrete. Sea water containing up to $35000 \mathrm{ppm}$ of sodium chloride and other salts is generally suitable as mixing water for plain concrete work. It is not fit for making reinforced concrete as the chlorides present in it may corrode reinforcement and produce efflorescence.

\section{Tests Conducted}

In this project we are going to compare the results of concrete with crushed C\&D wasted, with normal concrete by conducting following tests.

\section{Test carried out for fine and coarse aggregate}

1. Sieve analysis

2. Specific gravity test

\section{Test for workability of concrete}

1. Slump cone test

\section{Concrete load bearing capacity test}

1. Compressive strength test

\section{Discussion of Experimental Results}

\section{Fineness (Sieve analysis)}

The sieve analysis on the crushed C\&D wastes is given in the graph below. The fineness of the aggregate falls within the grading limits for fine aggregate. Comparing the results of crushed C\&D wastes with the normal sand used, the fineness of the C\&D wastes is more than the later. And also as we are crushing the C\&D wastes, it is our convenience to increase or decrease the fineness.

\section{Workability (slump cone test)}

Results shows the slump value of the slump cone test of the concrete using crushed C\&D wastes as fine aggregate. The slump value of the test is 26 . The slump formed was a true slump. It satisfies the conditions of the true slump, i.e., $25 \mathrm{~mm}-30 \mathrm{~mm}$. So the concrete using crushed C\&D wastes have enough workability to use in construction [5] purposes.

\section{Compressive stress (compressive test)}

Figure shows the comparison between the compressive stress of normal concrete and the concrete using crushed C\&D. Comparing the compressive stress of normal $\mathrm{M}_{20}$ grade concrete with concrete made with $\mathrm{C} \& \mathrm{D}$ wastes as a replacement to sand, it seems the latter is a little lagging behind the normal concrete. But as the design strength of $\mathrm{M}_{20}$ grade concrete is $20 \mathrm{~N} / \mathrm{mm}^{2}$ and the sample gave a value more than that, we believe the concrete can be used in construction, at the least for members which doesn't carry much load like walls etc. and also it can be used to construct concrete [6-9] hollow bricks.

\section{Conclusion}

There have been several possible applications of C\&D wastes in construction industry. However, probably due to lack of systematic studies, enough data is still not available for its wide spread use in construction. Test results indicate that the concrete made using crushed C\&D wastes gives almost as much as strength as normal concrete (about $30.66 \mathrm{~N} / \mathrm{mm}^{2}$ for 28 days) (Figures 1-5). From the above study, it is concluded that the crushed C\&D wastes can be used as a replacement for conventional sand as fine aggregate. Further studies should be done to know how extensively we can use the crushed C\&D wastes in 


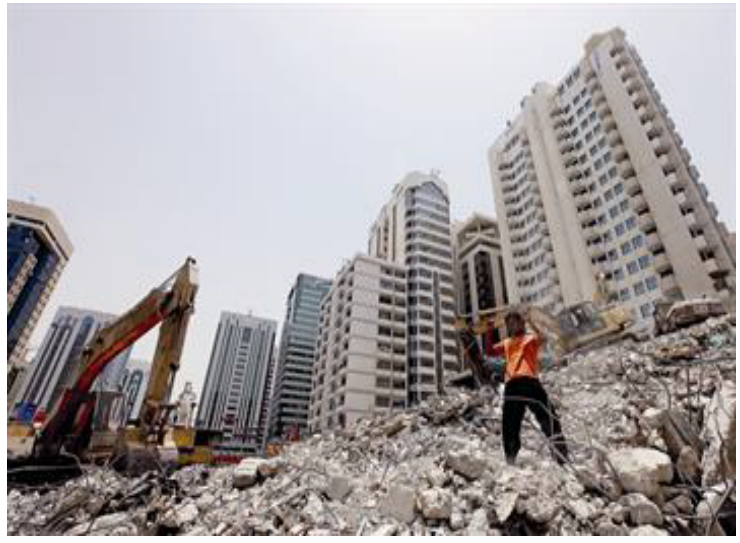

Figure 1: Construction wastes generated during the demolition of a building.

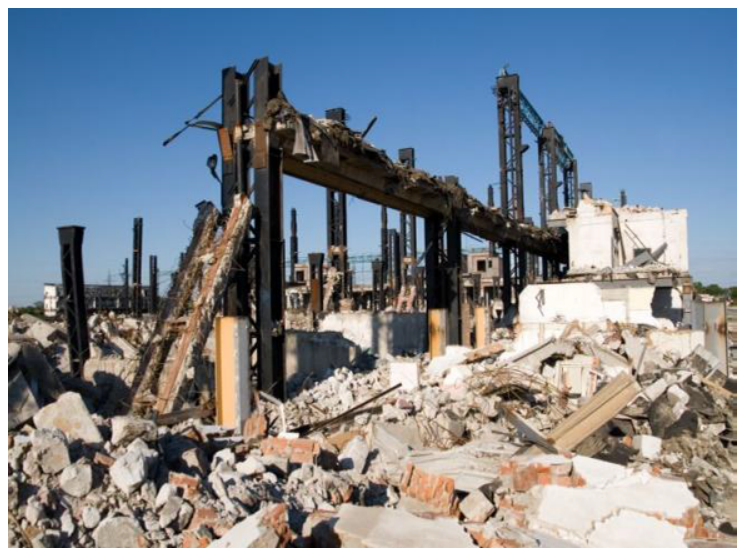

Figure 2: Demolition of a building due to wrong construction.

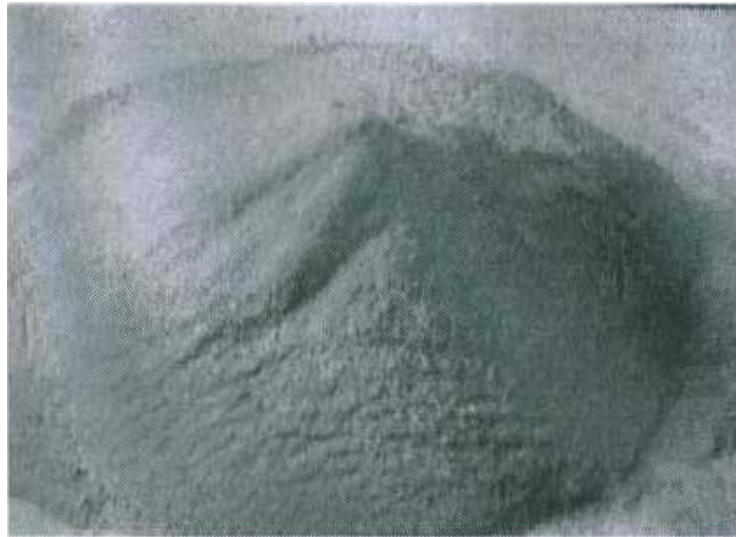

Figure 3: Crushed C\&D Waste.

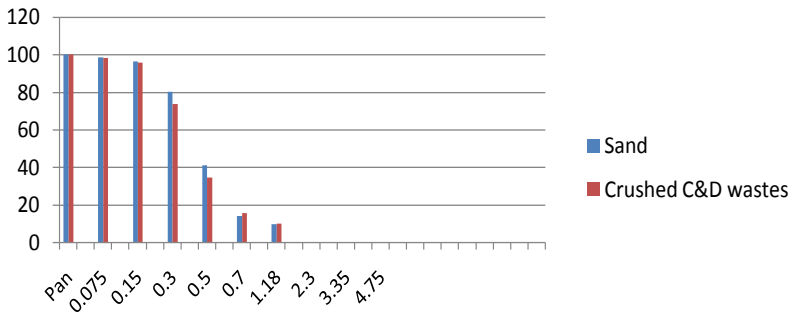

Figure 4: The sieve analysis on the crushed C\&D wastes.

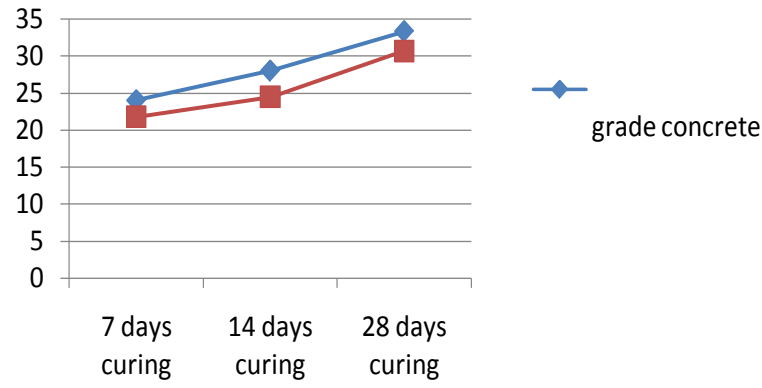

Figure 5: A comparison of compressive stress of Normal Concrete and Concrete made with C\&D wastes.

construction. Using crushed C\&D wastes in fresh concrete not only decreases the C\&D wastes in the country, but also it will decrease the use of river sand and M Sand, which are both becoming hard to come by, and also it will make the construction much cheaper. Even though more research is to be done on this topic, but the results will be rewarding.

\section{References}

1. Karin W, Lutz BG, Gunter M, Franz GS (2003) Building Materials from Waste Materials Transactions 44: 1255-1258.

2. Hendriks ChF, Jensen CMT (2007) Application of construction and demolition waste. IJITEE 46.

3. Kurt R (2012) Recycling and Reuse of Building Materials. National Pollution Prevention Center for Higher Education.

4. Md. Safiuddin (2010) Utilization of solid Wastes in Construction Materials. Int J Physics 5: 1952-1963.

5. Seeni A, Selvamony C, Kannan SU, Ravikumar MS (2012) Experimental Study of Partial Replacement of Fine Aggregate with Waste Material from China Clay Industries. Int J Comput Eng Res 2.

6. Mohan R (2012) Recycling of construction and demolition wastes. The master builder.

7. Karthik O, Haejin K, Colin L (2007) Crushed Returned Concrete as Aggregates for New Concrete. RMC REF Report: Crushed Returned Concrete as Aggregates for New Concrete.

8. Hansen TC, Narud H (1983) Strength of recycled concrete made from crushed concrete coarse aggregate. Concrete International 5: 79-83.

9. Sachin BK, Amol JM, Vijayshree AA (2012) Strength of concrete with different fine aggregates. Int J Scientific Eng Res 3. 